\title{
The Problem-Based Learning Process with A Cloud Learning Environment to Enhance Analysis Thinking
}

\author{
Sathiya Phunaploy ${ }^{1}$, Pinanta Chatwattana ${ }^{2} \&$ Pallop Piriyasurawong ${ }^{2}$ \\ ${ }^{1}$ Suan Sunandha Rajabhat University, Bangkok, Thailand \\ ${ }^{2}$ King Mongkut's University of Technology North Bangkok, Bangkok, Thailand \\ Correspondence: Sathiya Phunaploy, Suan Sunandha Rajabhat University, Bangkok, Thailand.
}

Received: March 20, 2021

Accepted: June 4, 2021

Online Published: June 7, 2021

doi:10.5430/ijhe.v10n6p45

URL: https://doi.org/10.5430/ijhe.v10n6p45

\begin{abstract}
This study, is aimed at 1) synthesizing the conceptual framework of the problem-based learning process with a cloud learning environment (PBL-CLE process), 2) developing the PBL-CLE process, and 3) studying the result of the development of the PBL-CLE process. The research instruments include 1) the conceptual framework, 2) the PBL-CLE process to enhance analysis thinking, 3) learning achievement, and 4) analysis thinking assessment form. The statistics used in this research are 1) mean, 2) standard deviation, and 3) t-test. The findings reveal that 1) the PBL-CLE process consists of four components: (1) Input includes learning objectives, content, learners, teacher and cloud learning, (2) PBL-CLE process includes problem posing, problem analysis, problem understanding, research procedure, knowledge synthesis, conclusion and evaluation, presentation, and assignment assessment, (3) Output includes analysis thinking, learning achievement, and satisfaction, and (4) Feedback includes analysis thinking and learning achievement; 2) The result of suitability assessment of the PBL-CLE process to enhance analysis thinking is at the highest level; 3) The students' learning achievement after the implementation of the PBL-CLE process to enhance analysis thinking is significantly higher than that before the implementation at a .01 level of statistical significance; and 4) The result of analysis thinking assessment after the learning process through the PBL-CLE process to enhance analysis thinking is at the very good level.
\end{abstract}

Keywords: problem-based learning, cloud learning environment, analysis thinking, learners 4.0

\section{Introduction}

\subsection{Introducing the Problem}

Thailand also needs to have a clear direction in its development to be in accordance with the different aspects of changing world trends. Learning is lifelong and helps develop other skills for the future, with two objectives, which are: first, to develop the mechanism and measures to promote education and lifelong learning and to enhance new capabilities needed for the new occupations emerges to support global technological trends, and second, to create a mechanism to develop the working and life skills needed by adolescents in the 21 st century so that they will have the capability to enter the workforce or the innovative skills to further their education or build their own business in the future (Ministry of Higher Education, Science, Research, \& Innovation, 2020).

\subsection{Background}

Problem-based learning has been widely used in many parts of the academic world. This approach can enhance learners' ability, motivation, and collaboration with others (Phonnong, 2019; Suryanti \& Supeni, 2019). When problem-based learning and instruction are integrated, they create active learning, the popular approach of this period in which the responsibilities of learners to be involved with instructional design are emphasized. Problem-based learning is aimed at teaching according to the learners' needs, which could be the needs of an individual or a group. However, problem-based learning still has a limitation, which is that learners' achievement depends on how well they practice the skills. Therefore, the teacher must encourage the learners to practice through guidance and providing necessary resources, which creates learning potential (Dagistani et al., 2016; Edwards et al., 2019; Klinmalee, 2018).

At present, cloud technology is being applied and integrated in classroom activities to increase the convenience of assigning and submitting homework (Palasonthi et al., 2019). Therefore, cloud learning is becoming an important 
alternative technology that lays the foundation for learning on digital platforms. This can be considered as replacing the internet icon with the cloud icon. Is equivalent with the cloud computing. It can be said that everything that works through the internet system called "Cloud-Learning" is the learning process that utilizes internet technology to process on the cloud (Plisorn \& Piriyasurawong, 2019).

Analysis thinking is a vital foundation of learning and living. A person with critical thinking ability has better abilities in other areas than others, including intelligence and living skills, which are the skills that everyone can develop (Klentien, 2017). This is in accordance with Bangpoophamorn (2016), who stated that analytical thinking is a higher level of cognitive skill than understanding. It is the classification of various elements of one thing or one subject, whether an object or event, to find facts about those elements.

Thai Education 4.0 is focused on creating knowledge from individual interests and from gathering people who are motivated to be a team. Learning can then happen anywhere and at any time, both in and out of class. The concept of Thai Education 4.0 is in harmony with $21^{\text {st }}$-century learning, which helps students acquire skills in various areas such as independent learning skills, cooperation skills, analysis and problem-solving skills, innovation skills, research and design skills, and entrepreneur skills, to name a few (Sriharee, 2018). Thus, Education 4.0 aims to educate each individual so that the students gain sufficient analytical skills to create a product (Sinlarat et al., 2016).

With this learning process, learners will be able to learn anywhere and anytime through wireless devices with internet connection. The problem-based learning process with a cloud learning environment (PBL-CLE process) will support data, content, learning objectives, and teaching aids. It will also enhance the learners' analysis thinking. Moreover, the researcher has synthesized the principles and theories related to problem-based learning, cloud learning environment, and analysis thinking to write the conceptual framework for developing the PBL-CLE process to enhance analysis thinking and carefully study the developed process.

\subsection{Research Objectives and Hypotheses}

The objectives of this research are as follows:

1) To synthesize the conceptual framework of the PBL-CLE process to enhance analysis thinking;

2) To develop the PBL-CLE process to enhance analysis thinking;

3) To study the results of the PBL-CLE process to enhance analysis thinking;

The researcher studies the suitability of the development and makes the following hypotheses:

1) The result of the assessment of the suitability of the PBL-CLE process to enhance analysis thinking is at the high level.

2) The learning achievement of the learners after learning through the PBL-CLE process to enhance analysis thinking is significantly higher than that before the learning at the .01 level of statistical significance.

3) The analysis thinking of the learners after learning through the PBL-CLE process to enhance analytsis thinking are at the good level.

\section{Research Methodology}

This research is aimed at developing the PBL-CLE process to enhance analysis thinking based on the development concept of the ADDIE model (Khemmani, 2010) and system approach (Brown \& Moberg, 1980) as well as utilizing problem-based learning as the foundation of the design and development. The researcher designs and conducts the research in accordance with the three research objectives. The detail of the research is as follows:

1) Analysis is the first and most important stage because it will affect the following stages. In this stage, learning objectives, content, learners, the teacher, cloud learning environment, problem-based learning, learning achievement, analysis thinking, and satisfaction are analyzed to frame input, problem-based learning environment, evaluation, and feedback.

2) Design is the stage for designing the PBL-CLE process. It is the crucial stage toward the set goals. The researcher designs learning strategies from the analysis stage.

3) Development is the stage following design. After the researcher gets the result from the design stage, he develops the PBL-CLE process according to that design and readies it for the implementation stage.

4) Implementation is the stage in which the learning process is developed. The developed PBL-CLE process is implemented by the target group, who are experienced experts in instructional design, information technology, problem-based learning, and mathematics, to evaluate the suitability of the developed learning process. 
5) Evaluation is the stage for evaluating the suitability of the PBL-CLE process and revising it to secure the efficient and authentic learning and teaching process.

Phase 1 - The researcher synthesized the conceptual framework of the PBL-CLE process to enhance analysis thinking. In this phase, the researcher studied, researched, analyzed, and synthesized documents, data, and literature related to the PBL-CLE process to enhance analysis thinking, as seen in Figure 1.

The problem-based learning process

(Thanapud, 2014; The Office of the Education Council, 2009; Ulger, 2018)

Step 1 Problem posing

Step 2 Problem analysis

Step 3 Problem understanding

Step 4 Researching

Step 5 Knowledge synthesis

Step 6 Conclusion and evaluation

Step 7 Presentation and performance assessment

\section{Cloud learning environment}

(Chang et al., 2010; Sanchez et al., 2015)

1. Learning outcomes and learning resources can be stored and shared on cloud.

2. Learners can learn according to their interest as long as they can access the network.

3. Learners can collaborate to create knowledge and correspond conveniently everywhere via cloud.

4. Learners can choose suitable resources and follow up their own learning progress.
Problem-based learning process

with a cloud learning environment to enhance analysis thinking

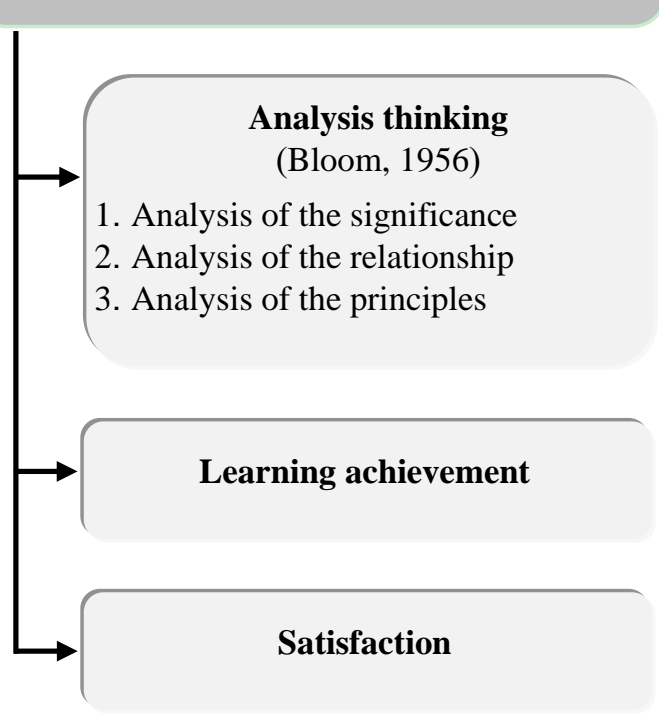

Figure 1. The framework of the PBL-CLE process to enhance analysis thinking

Figure 1 presents the conceptual framework of the PBL-CLE process to enhance analysis thinking, which is developed from the foundation principle and the theories related to the development of the PBL-CLE process, consisting of the problem-based learning process, cloud learning environment, analysis thinking, learning achievement, and satisfaction.

Phase 2 - The synthesis of the PBL-CLE process to enhance analysis thinking skills in this phase, including studying, researching, analyzing, and synthesizing documents, data, and research related to the design of the PBL-CLE process, which is the synthesis of problem-based theories presented by various renowned scholars; the synthesized outcomes of problem-based learning are summarized in Table 1. 
Table 1 . The synthesis of problem-based learning

\begin{tabular}{|c|c|c|c|c|c|c|c|c|c|}
\hline Characteristic & 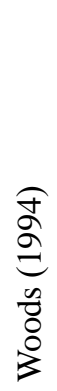 & 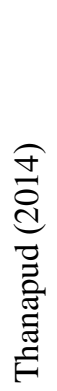 & 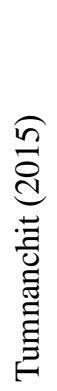 & 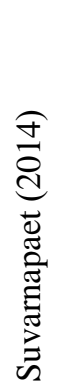 & 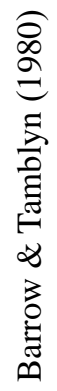 & 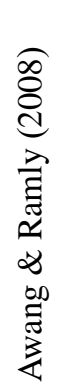 & 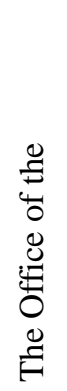 & 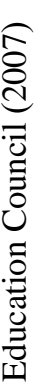 & 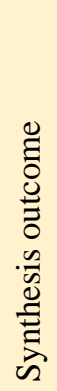 \\
\hline Content study & $\checkmark$ & & & & & & & & \\
\hline Problem posing & $\checkmark$ & $\checkmark$ & $\checkmark$ & $\checkmark$ & & & & $\checkmark$ & $\checkmark$ \\
\hline Problem analysis & $\checkmark$ & & $\checkmark$ & $\checkmark$ & $\checkmark$ & & & & $\checkmark$ \\
\hline Problem understanding & $\checkmark$ & $\checkmark$ & $\checkmark$ & & $\checkmark$ & & & $\checkmark$ & $\checkmark$ \\
\hline Learning objectives & $\checkmark$ & & & & $\checkmark$ & & & & \\
\hline Problem-solving planning & $\checkmark$ & & & & & & & & \\
\hline \multicolumn{10}{|l|}{ Problem-solving procedures } \\
\hline Research procedures & & $\checkmark$ & & $\checkmark$ & $\checkmark$ & $\checkmark$ & & $\checkmark$ & $\checkmark$ \\
\hline Knowledge synthesis & $\checkmark$ & $\checkmark$ & & $\checkmark$ & & $\checkmark$ & & $\checkmark$ & $\checkmark$ \\
\hline $\begin{array}{l}\text { Presentation and performance } \\
\text { assessment }\end{array}$ & & $\checkmark$ & & $\checkmark$ & & $\checkmark$ & & $\checkmark$ & $\checkmark$ \\
\hline Problem-solving innovation creating & & & & & & $\checkmark$ & & & \\
\hline Problem-solving presentation & & & $\checkmark$ & & & & & & \\
\hline Principle conclusion & $\checkmark$ & & & & & & & & \\
\hline Conclusion and evaluation & & $\checkmark$ & $\checkmark$ & & & & & $\checkmark$ & $\checkmark$ \\
\hline Conclusion and assessment & & & $\checkmark$ & $\checkmark$ & $\checkmark$ & & & & \\
\hline
\end{tabular}

Table 1 presents the seven steps of the synthesis of problem-based learning as follows:

Step 1: problem posing includes instructors providing problems for learners in accordance with the learning objectives, course lesson plans, and the learning content of the learners' interest.

Step 2: problem analysis includes finding the causes of the problems. When the causes are discovered, it will lead to the problem-solving planning and analysis.

Step 3: problem understanding is the process whereby learners analyze the causes of the problems to gain deep understanding of those problems.

Step 4: researching procedure is the process whereby learners start researching information on the topic of interest.

Step 5: knowledge synthesis is the process whereby learners share the knowledge they have gained from their research among their peers.

Step 6: conclusion and evaluation is the process wherein learners from each group conclude their learned knowledge in their own groups, then all groups conclude the body of knowledge from what they have gained during the problem-solving process together.

Step 7: presentation and performance assessment is the process wherein learners organize the body of knowledge they have gained from researching. After that, each group makes a presentation.

Phase 3 - The PBL-CLE process to enhance analysis thinking in this phase includes studying, researching, analyzing, and synthesizing documents, data, and research related to said process. The process of development consists of four elements, as shown in Figure 2. 


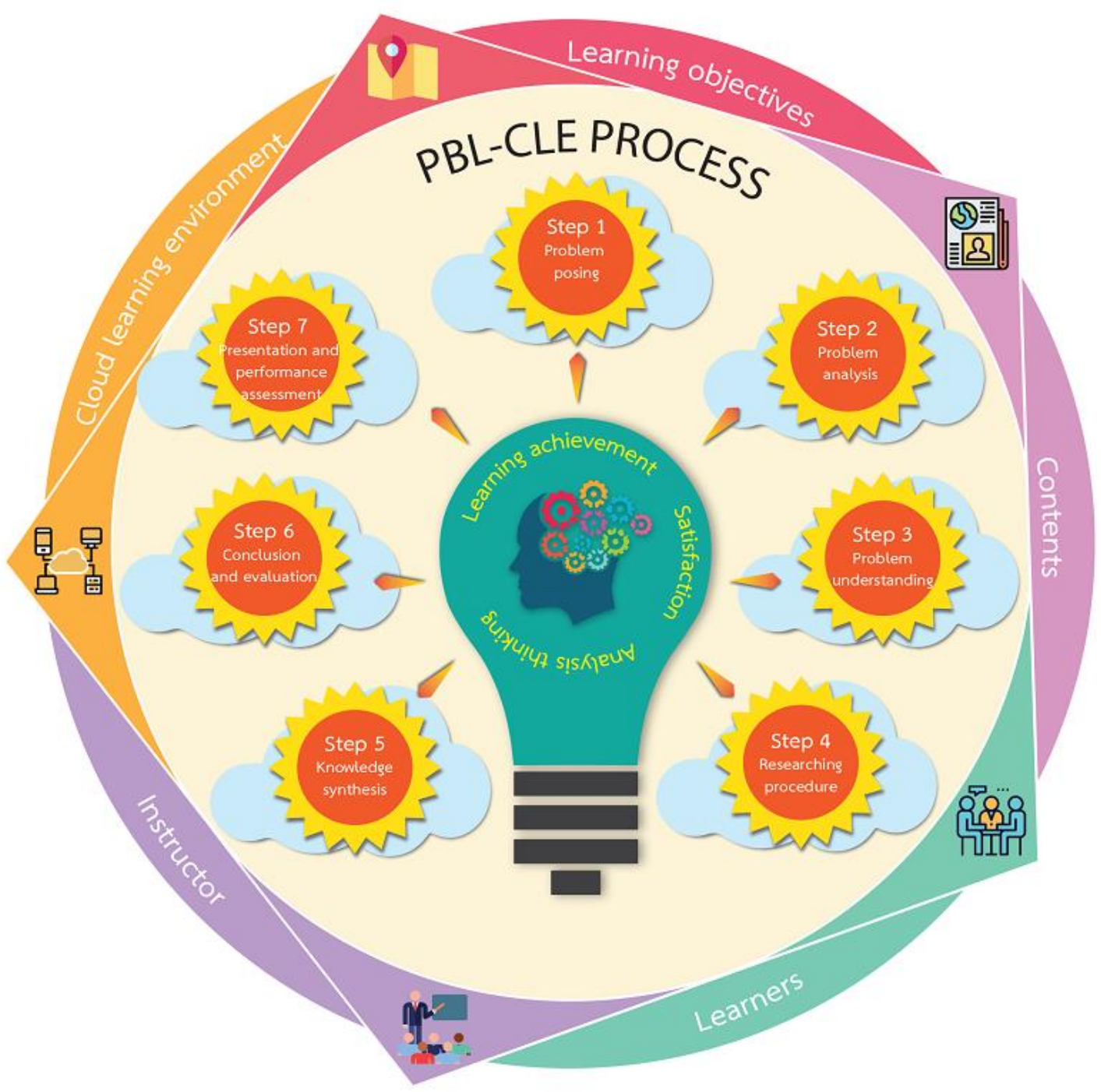

Figure 2. The PBL-CLE process to enhance analysis thinking

Figure 2 presents four elements of the development process of the PBL-CLE process to enhance analysis thinking as follows:

Component 1: Input consists of several aspects related to the PBL-CLE process as shown below.

- Learning objectives identify what learners aim to achieve, including knowledge, skills, and attitude.

- Learning content is the information that the teacher provides for learners to apply in the problem-solving process. The content needs to be critical and suitable for teaching analysis thinking, so the teacher should prepare beforehand.

- Learners are those who enroll in the particular course.

- The teacher is the person who provides, organizes, and facilitates the knowledge, skills, and attitudes for learners.

- The cloud learning environment is the technology on the cloud. There is no need to provide servers and rent a storage area. Examples of cloud technology are Google Meet, Google Sheet, Google Forms, and Google Classroom.

Component 2: The problem-based learning process is an internal process that utilizes the steps of problem-based theories to enhance analysis thinking. The researcher synthesized the steps of problem-based learning. The result is as follows:

Step 1: Problem posing includes instructors providing problems for learners in accordance with the learning objectives, course lesson plans, and learning content of the learners' interest to stimulate the learners' interest, ability 
to analyze, and ability to scrutinize the problems.

Step 2: Problem analysis includes finding the causes of the problems. When the causes are discovered, it will lead to problem-solving planning and analysis. The analysis is the process whereby the learners scrutinize and collect essential information. Learners must have sufficient information to analyze the causes of the problems.

Step 3: Problem understanding is the process whereby learners analyze the causes of the problems to acquire deep understanding of those problems. Learners must be able to explain the causes of the problems and the factors related to those problems.

Step 4: Researching procedure is the process wherein the learner starts researching information on the topic of interest. There are many ways to research, and there are many ways to solve the problems.

Step 5: Knowledge synthesis is the process whereby learners share the knowledge they have gained from their research among their peers via group discussion. Thereafter, learners synthesize the information from the discussion to create the body of knowledge that can actually solve the problem.

Step 6: Conclusion and evaluation is the process wherein learners from each group conclude their learned knowledge in their own groups, then all groups conclude the body of knowledge from what they have gained during the problem-solving process together.

Step 7: Presentation and performance assessment is the process whereby learners organize the body of knowledge they have gained from researching. Thereafter, each group makes a presentation. The teacher must have a role in assessing the learners' performance.

Component 3: Output assessment is the result of learning management according to the developed procedures, which includes learning achievement, analysis thinking, and satisfaction.

Table 2. The synthesis of analysis thinking

\begin{tabular}{|c|c|c|c|c|c|c|c|}
\hline Characteristic & 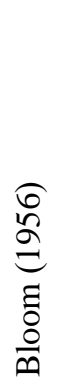 & 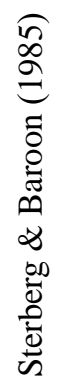 & 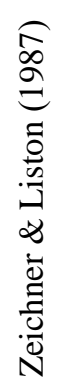 & 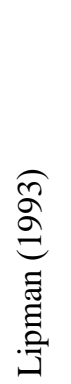 & 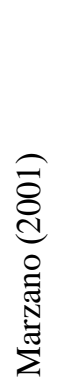 & 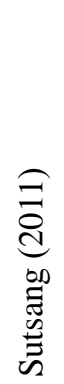 & 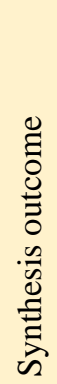 \\
\hline Analysis of the significance & $\checkmark$ & $\checkmark$ & & $\checkmark$ & $\checkmark$ & $\checkmark$ & $\checkmark$ \\
\hline Analysis of the relationship & $\checkmark$ & $\checkmark$ & & $\checkmark$ & $\checkmark$ & $\checkmark$ & $\checkmark$ \\
\hline Analysis of the principles & $\checkmark$ & $\checkmark$ & & $\checkmark$ & $\checkmark$ & $\checkmark$ & $\checkmark$ \\
\hline Hypotheses posing & & & & $\checkmark$ & & & \\
\hline Opinion expressing & & & & $\checkmark$ & & & \\
\hline Decision making & & & & $\checkmark$ & & & \\
\hline Applying & & & & & $\checkmark$ & & \\
\hline Ability to give details & & & $\checkmark$ & & & & \\
\hline Ability to give reasons & & & $\checkmark$ & & & & \\
\hline Ability to perform & & & $\checkmark$ & & & & \\
\hline
\end{tabular}

Table 2 is a summary of analysis thinking synthesis provided by renowned scholars. The researcher divided the results into three steps as shown in Table 3. 
Table 3. Characteristics of analysis thinking

\begin{tabular}{ll}
\hline \multicolumn{1}{c}{ Analysis thinking } & \multicolumn{1}{c}{ Evaluation target } \\
\hline Analysis of the significance & $\begin{array}{l}\text { The ability to analyze the importance and characteristics } \\
\text { of the formulas, and the ability to compare information }\end{array}$ \\
Analysis of the relationship & $\begin{array}{l}\text { The ability to find the relationship between formulas, and } \\
\text { the ability to list the relationship between the result and } \\
\text { the problem } \\
\text { The ability to analyze the principle of applying the formulas } \\
\text { to solve the problems }\end{array}$
\end{tabular}

Component 4: Feedback includes the analysis thinking and the learning achievement, which are the result of the developed learning procedures that will be used as feedback in developing the input and the process.

Phase 4 - The study of the PBL-CLE process to enhance analysis thinking is the process of studying the suitability of the development of the PBL-CLE process by experts in the field of problem-based learning instructional design and development, information technology, and mathematics. The analysis and interpretation criteria created by Kanasutra (1995) were applied:

Table 4. Average score range and interpretation

\begin{tabular}{cl}
\hline Average score range & Interpretation \\
\hline $4.50-5.00$ & Highest suitability level \\
$3.50-4.49$ & High suitability level \\
$2.50-3.49$ & Average suitability level \\
$1.50-2.49$ & Low suitability level \\
$1.00-1.49$ & Lowest suitability level \\
\hline
\end{tabular}

\section{Results}

\subsection{The Result of the Assessment of the Suitability of the PBL-CLE Process to Enhance Analysis Thinking}

The result on the suitability of the PBL-CLE process to enhance analysis thinking from the development of said process can be concluded in three parts: 1) the result of the suitability of said process to enhance analysis thinking in the wider picture, 2) the result of the suitability of saidprocess to enhance analysis thinking presented by components, and 3) the result of the suitability of said process to enhance analysis thinking in terms of authentic use as presented below.

Table 5. Overview on the result of the suitability of the PBL-CLE process to enhance analysis thinking

\begin{tabular}{lccc}
\multicolumn{1}{c}{ Description } & Mean & SD & Interpretation \\
\hline $\begin{array}{l}\text { 1. The learning process developed in compliance with the research } \\
\text { objectives: }\end{array}$ & 4.83 & 0.39 & Highest \\
(1) To promote analysis thinking & & & \\
(2) To promote learning achievement & 4.83 & 0.39 & Highest \\
2. Learning process components include: & & & \\
$\quad$ (1) Input & & & \\
(2) Process & & & \\
(3) Output & 4.92 & 0.29 & Highest \\
(4) Feedback & 4.75 & 0.45 & Highest \\
3. Classification of learning process components for designing learning and \\
teaching management is precisely and continuously conducted \\
4. Learning processes in each component are related to one another \\
5. Sequencing of learning process components is suitable and easy to \\
understand
\end{tabular}


Table 5 shows that the result of the suitability of the PBL-CLE process to enhance analysis thinking in the wider picture is at the highest level (mean $=4.81, \mathrm{SD}=0.40$ ). When considering by detailed aspects, it is found that every detailed aspect is rated at the highest level, which means the overall is also at the highest level; therefore the PBL-CLE process can be applied as a guideline to improve the learning and teaching process.

Table 6. The result of the suitability of the PBL-CLE process to enhance analysis thinking presented by components

\begin{tabular}{lccc}
\hline \multicolumn{1}{c}{ Description } & Mean & SD & Interpretation \\
\hline $\begin{array}{l}\text { 1. Input (includes learning objectives, content, learners, the teacher, and } \\
\text { cloud learning) }\end{array}$ & 4.67 & 0.49 & Highest \\
$\begin{array}{l}\text { 2. PBL-CLE process (includes problem posing, problem analysis, } \\
\text { problem understanding, research study, knowledge synthesis, } \\
\text { conclusion and evaluation, and presentation and performance }\end{array}$ & 4.92 & 0.29 & Highest \\
assessment) & & & \\
$\begin{array}{l}\text { 3. Output (includes analysis thinking, learning achievement, and } \\
\text { satisfaction) }\end{array}$ & 4.75 & 0.45 & Highest \\
$\begin{array}{l}\text { 4. Feedback (includes analysis thinking and learning achievement) } \\
\text { Overall suitability }\end{array}$ & 4.75 & 0.45 & Highest
\end{tabular}

Table 6 shows that the result on the suitability of the PBL-CLE process to enhance analysis thinking presented by components is at the highest level (mean $=4.77, \mathrm{SD}=0.42$ ). It can be concluded that said process can be developed as a guideline to promote it for enhancing analysis thinking. This result is compliant with the study of Linthaluek et al. (2020), who stated that all components in the learning and teaching process system must be related. The researcher divided the four components of the process with consideration of theories and principles to achieve the desired goals for the improvement of learning and teaching.

Table 7. The result of the suitability of the PBL-CLE process to enhance analysis thinking in terms of authentic use

\begin{tabular}{lccc}
\hline \multicolumn{1}{c}{ Description } & Mean & SD & Interpretation \\
\hline $\begin{array}{l}\text { 1. This developed learning process can serve the purpose of learning } \\
\text { and teaching to enhance undergraduates' analysis thinking }\end{array}$ & 4.75 & 0.45 & Highest \\
$\begin{array}{l}\text { 2. This developed learning process is suitable for learning and teaching } \\
\text { to enhance undergraduates' analysis thinking }\end{array}$ & 4.92 & 0.29 & Highest \\
$\begin{array}{l}\text { 3 The developed PBL-CLE supports the application of cloud learning } \\
\text { environment }\end{array}$ & 4.67 & 0.49 & Highest \\
$\begin{array}{l}\text { 4. This developed learning process is plausible for authentic use } \\
\text { Overall suitability }\end{array}$ & 4.75 & 0.45 & Highest \\
\hline
\end{tabular}

Table 7 shows that the result on the suitability of the PBL-CLE process to enhance analysis thinking in terms of authentic use is at the highest level (mean $=4.77, \mathrm{SD}=0.42$ ). It can be concluded that the developed PBL-CLE process to enhance analysis thinking has essential components suitable for the learning and teaching process, which can be used as a guideline to promote learning achievement and higher-order thinking skills (Sekarini et al., 2020).

3.2 The Result Shows the Comparison of the Undergraduates' Learning Achievement before and after Using the PBL-CLE Process to Enhance Analysis Thinking

The result of the comparison of the learning achievement of 19 undergraduates who enrolled in the course MFS2303 (spreadsheet for data analysis) in the second semester of the academic year 2020, before and after using the PBL-CLE process to enhance analysis thinking, is presented in Table 8.

Table 8. The comparison of the undergraduates' learning achievement before and after using the PBL-CLE process to enhance analysis thinking

\begin{tabular}{lcccccc}
\hline $\begin{array}{c}\text { Score of learning } \\
\text { achievement }\end{array}$ & $\mathrm{n}$ & Full score & Mean & SD & T & Sig. \\
\hline Before & 19 & 80 & 37.11 & 14.40 & 51.10 & $.00^{* *}$ \\
After & 19 & 80 & 58.11 & 15.59 & & \\
\hline 01
\end{tabular}

$* * \mathrm{p}<.01$ 
From Table 8, the result of comparing the undergraduates' learning achievement before and after using the PBL-CLE process to enhance analysis thinking reveals that the score after learning is significantly higher than the score before learning at the .01 level of statistical significance. When considering the average score of learning achievement, the score after learning (mean $=58.11, \mathrm{SD}=15.59)$ is significantly higher than that before learning (mean $=37.11, \mathrm{SD}=$ 14.40). It can be concluded that the PBL-CLE process to enhance analysis thinking can help increase the learners' achievement.

\subsection{The Result Shows the Undergraduates' Analysis Thinking after Using the PBL-CLE Process to Enhance Analysis Thinking}

After the undergraduate learners studied through the PBL-CLE process to enhance their analysis thinking, they were assigned to perform four individual problem-solving tasks of said process to enhance said skills. Then, their analysis thinking development was assessed via an analysis thinking assessment form and criteria developed by the researcher. When the learners could reach 15 points or higher for the authentic performance assessment, they would be considered to have achieved analysis thinking development. However, if their score was under 15, they would be considered as not having acquired analysis thinking development. The researcher adapted Khanittha's rubric scoring for authentic assessment (2016) as the research instrument, as shown in Table 9.

Table 9. Average score range and the interpretation from the authentic assessment

\begin{tabular}{cl}
\hline Average score range & \\
\hline $18-20$ & Very good \\
$15-17$ & Good \\
$12-14$ & Fair \\
$9-11$ & Needs improvement
\end{tabular}

Table 10. The comparison of the undergraduates' learning achievement before and after using the PBL-CLE process to enhance analysis thinking

\begin{tabular}{cccccrc}
\hline \multirow{2}{*}{ Learner No. } & \multicolumn{2}{c}{ Evaluators $(\mathrm{n}=2)$} & \multirow{2}{*}{ Total } & Mean & Percentage & Interpretation \\
\cline { 2 - 3 } & Evaluator 1 & Evaluator 2 & & & & \\
\hline 1 & 19 & 20 & 39 & 19.50 & 97.50 & Very good \\
2 & 20 & 20 & 40 & 20.00 & 100.00 & Very good \\
3 & 19 & 19 & 38 & 19.00 & 95.00 & Very good \\
4 & 20 & 20 & 40 & 20.00 & 100.00 & Very good \\
5 & 18 & 19 & 37 & 18.50 & 92.50 & Very good \\
6 & 17 & 18 & 35 & 17.50 & 87.50 & Very good \\
7 & 20 & 20 & 40 & 20.00 & 100.00 & Very good \\
8 & 19 & 18 & 37 & 18.50 & 92.50 & Very good \\
9 & 20 & 20 & 40 & 20.00 & 100.00 & Very good \\
10 & 19 & 19 & 38 & 19.00 & 95.00 & Very good \\
11 & 18 & 19 & 37 & 18.50 & 92.50 & Very good \\
12 & 18 & 18 & 36 & 18.00 & 90.00 & Very good \\
13 & 20 & 20 & 40 & 20.00 & 100.00 & Very good \\
14 & 20 & 20 & 40 & 20.00 & 100.00 & Very good \\
15 & 19 & 20 & 39 & 19.50 & 97.50 & Very good \\
16 & 20 & 20 & 40 & 20.00 & 100.00 & Very good \\
17 & 18 & 19 & 37 & 18.50 & 92.50 & Very good \\
18 & 19 & 20 & 39 & 19.50 & 97.50 & Very good \\
19 & 20 & 20 & 40 & 20.00 & 100.00 & Very good \\
Average & 19.11 & 19.42 & 38.53 & 19.26 & 96.32 & Very good \\
\hline
\end{tabular}


From Table 10, the result shows the undergraduates' analysis thinking after using the PBL-CLE process to enhance said skills as assessed by two evaluators. It is found that the learners' score of analysis thinking is at the "very good" level, beyond the posed hypothesis (the third hypothesis) of the study, which stated that their analysis thinking after studying using PBL-CLE to enhance said skills would be at the good level. When considering the average score on analysis thinking of all learners, out of 20, it was 19.26, or $96.32 \%$. Every learner passed the set criteria of $80 \%$.

\section{Conclusion and Discussion}

The result after the undergraduate learners studied through the PBL-CLE process to enhance analysis thinking is compliant with the research objectives. The conclusion and discussion are presented as follows:

1) The synthesized conceptual framework of the PBL-CLE process to enhance analysis thinking includes the problem-based learning process, cloud learning environment, analysis thinking, learning achievement, and satisfaction. This is compliant with Thiaposri (2016), who synthesized the cloud learning conceptual framework for the digital learning resources for enhancing students' learning by gathering cloud computing tools and services so that the teacher and students could conduct activities using various tools without the limitation of time and space.

2) The developed PBL-CLE process to enhance analysis thinking has four components: Component 1, Input (includes learning objectives, learning content, learners, the teacher, and cloud learning), Component 2, PBL-CLE process (includes problem posing, problem analysis, problem understanding, researching, knowledge synthesis, conclusion and evaluation, and presentation and performance assessment), Component 3, Output (includes analysis thinking, learning achievement, and satisfaction), and Component 4, Feedback (includes analysis thinking and learning achievement). The result of the assessment of the suitability of the developed process, presented in three dimensions (in an overview, by components, and in terms of authentic use) is at the highest level. This implies that the application of the ADDIE model (Hadi et al., 2017), instructional design, and system approach (Montre, 2018) with the emphasis on the learners' participation in problem-based analysis thinking activities, the analysis thinking and learning achievement are increased. This is in compliance with Amornkitpinyo and Piriyasurawong's research (2017) on two-stage methodologies: 1) the first stage is to synthesize the concept of the framework of the structural equation model of mobile cloud learning acceptance for higher education students in the 21st century, and 2) the second stage proposes the design structural equation model of mobile cloud learning acceptance for higher education students in the 21st century. Moreover, Piriyasurawong (2017) also used ARCS motivation of the social cloud model in social media activities and classes because the teacher assigned online assignments and conducted online activities and communication with the learners. The learners made comments and shared knowledge through online simulations. This process of learning encourages active learning in every learning process activity. Finally, Baysal (2017) improved learners' thinking skills by using problem-based learning for the learners to practice self-assessment and awareness in their thinking and problem-solving methods. Fery et al. (2017) studied the learners' mathematical literacy after using problem-based learning. They found that the score after learning via problem-based learning was significantly higher than that before the learning.

3) The result of the development of the PBL-CLE process to enhance analysis thinking reveals that (1) the comparison of the undergraduates' learning achievement score before and after using said process to enhance analysis thinking showed the score after learning was significantly higher than that before learning at a .01 level of statistical significance. This means the students were encouraged to learn anytime and anywhere with the use of various useful electronic devices that help them in problem solving. This is compliant with Pongsawat and Wannapiroon (2020), who found that the students' learning achievement after using the flipped classroom and scientific inquiry teaching method was significantly higher than in those who studied with the traditional teaching method at a .01 level of statistical significance. (2) The result for the analysis thinking after using the PBL-CLE process to enhance said skills through problem-solving activities was evaluated by rubric scoring on important analysis skills, relationship analysis skills, and principle analysis skills in compliance with Jewpanich (2016), who developed a project-based learning model through online discussion to promote undergraduates' problem-solving skills. His study found that every student passed the expected criteria (80\%); the lowest got $88.89 \%$ and the highest got $94.44 \%$, as posed in the hypothesis.

\section{References}

Amornkitpinyo, T., \& Piriyasurawong, P. (2017). The concept framework of structural equation model of mobile cloud learning acceptance for higher education students in the $21^{\text {st }}$ century. TEM Journal, 6(3), 464-468. https://dx.doi.org/10.18421/TEM63-05 
Awang, H., \& Ramly, I. (2008). Creative thinking skill approach through problem-based learning: Pedagogy and practice in the engineering classroom. International Journal of Human and Social Sciences, 3(1), 18-23.

Barrows, H. S., \& Tamblyn, R. M. (1980). Problem-based learning: An approach to medical education.

Baysal, Z. N. (2017). The problem-based learning process: Reflections of pre-service elementary school teachers. Educational Research and Reviews, 12(4), 177-188. https://doi.org/10.5897/ERR201 6.3045

Bloom, B. S. (1956). Taxonomy of educational objectives. McKay.

Brown, W. B., \& Moberg, D. J. (1980). Organization theory and management: A macro approach. John Wiley and Sons.

Chang, V., Bacigalupo, D., Wills, G., \& De Roure, D. (2010). A categorisation of cloud computing business models, poster paper. In CCGrid 2010 IEEE Conference. https://doi.org/10.1109/CCGRID.2010.132

Dagistani, A., Al Hejaili, F., Binsalih, S., Al Jahdali, H., \& Al Sayyari, A. (2016). Stress in medical students in a problem-based learning curriculum. International Journal of Higher Education, 5(3), 12-19. https://doi.org/10.5430/ijhe.v5n3p12

Edwards, D. J., Kupczynski, L., \& Groff, S. L. (2019). Learning styles in problem-based learning environments: Impacts on student achievement and professional preparation in university-level physical therapy courses. International Journal of Higher Education, 8(3), 206-213. https://doi.org/10.5430/ijhe.v8n3p206

Fery, M. F. Wahyudin, \& Tatang, H. (2017). Improving primary students' mathematical literacy through problem-based learning and direct instruction. Educational Research and Reviews, 12(4), 212-219. https://doi.org/10.5897/err2016.3072

Hadi, S. P. I., Kuntjoro, T., Sumarni, S., Anwar, M. C., Widyawati, M. N., \& Pujiastuti, R. S. E. (2017). The development of e-partograph module as a learning platform for midwifery students: The ADDIE model. Belitung Nursing Journal, 3(2), 148-156. https://doi.org/10.33546/bnj.77

Howard, B., \& Robyn, T. (1980) Problem-based learning: An approach to medical education. Springer Publishing Company. https://doi.org/10.33546/bnj.77

Jewpanich, C. (2016). Development of project-based learning using discussion and lesson-learned methods via social media model for enhancing problem solving skills of undergraduate students in education. [Doctoral dissertation, King Mongkut's University of Technology North Bangkok]. https://doi.org/10.5539/ies.v8n6p24

Khemmani, T. (2010). Science of teaching: Knowledge of efficient learning process management. Chulalongkorn University Press.

Klentien, U. (2017). The development of virtual science laboratory with blended learning for developing analytical thinking skill of secondary school students. [Doctoral dissertation, King Mongkut's University of Technology North Bangkok].

Klinmalee, R. (2018). The development of instructional package to enhance practical learning using online and offling problem-based learning with scaffolding system. [Doctoral dissertation, King Mongkut's University of Technology North Bangkok].

Linthaluek, S., Chatwattana, P., \& Piriyasurawong, P. (2020). Research-based learning using digital wisdom repository model for improving research proposal skill of graduated students. Technical Education Journal: King Mongkut's University of Technology North Bangkok, 11(1), 112-119.

Lipman, M. (1993). Thinking children and education. Kendall/Hunt.

Marzano, R. J. (2001). Designing a new taxonomy of educational objective. Corwin Press Inc.

Ministry of Higher Education, Science, Research, and Innovation. (2020). Policy and strategy for higher education, science, research, and development, 2020-2027 and science, Research, and innovation plan, 2022.

Montre, W. (2018). Design of an imagineering through cloud learnig to promote innovative construction skills and technology acceptance. [Doctoral dissertation, King Mongkut's University of Technology North Bangkok].

Palasonthi, K., Piriyasurawong, P., \& Chatwattana, P. (2019). Cloud learning is STEAM education model by augmented reality technology to develop creativity and innovation skills for undergraduate students. Technical Education Journal: King Mongkut's University of Technology North Bangkok, 10(2), 256-264.

Phonnong, I. (2019). A study of basic concepts, instructional activities and learning processes, and effectiveness of 
problem-based learning. Journal of Education Burapha University, 30(2), 70-85.

Piriyasurawong, P. (2017). Active learning using ARCS motivation of social cloud model to enhance communication skills in foreign language. TEM Journal, 8(1), 290-297. https://dx.doi.org/10.18421/TEM81-40

Pongsawat, P., \& Wannapiroon, P. (2020). Development of a flipped classroom by scientific inquiry learning on a social cloud model to enhance lifelong learning skills for undergraduate students. Technical Education Journal: King Mongkut's University of University of Technology North Bangkok, 11(2), 67-76.

Sanchez, M., Aguilar, J., Cordero, J., \& Valdiviezo, P. (2015). A smart learning environment based on cloud learning. International Journal of Advanced Information Science and Technology (IJAIST), 39(39), 39-52. https://www.researchgate.net/publication/288832016

Secretary General of the Education Council (2008). Strategy for educational quality development (national agenda) (2008-2012). The Office of the Education Council, Ministry of Education.

Sinlarat, P., Kamdit, S., ManuSawat, C., Wisaritapa. W., \& Meesaeng, N. (2016). Education 0.4 is more than education. Chulalongkorn University Press.

Sriharee, G. (2018). Software engineering prospective on digital game-based learning for Thailand education 4.0. The Journal of KMUTNB, 28(2), 477-488. https://doi.org/10.14416/j.kmutnb.2018.04.001

Sternberg, R. J., \& Baron, J. B. (1985). A statewide approach to measuring critical thinking skills. Educational Leadership, 43(2), 40-43.

Sudsang, W. (2011). Critical thinking and creative thinking. Children's Club.

Suryanti, H. H. S., \& Supeni, S. (2019). A problem-based learning (PBL) model in developing students' soft skills aspect. International Journal of Higher Education, 8(8), 62-69. https://doi.org/10.5430/ijhe.v8n8p62

Suvarnapaet, P. (2014). The development of blended learning model using problem-based learning and inquiry-based learning to enhance physics expectation of undergradyate students. [Doctoral dissertation, King Mongkut's University of Technology North Bangkok].

Thaiposri, P. (2016). Reasonable inquiry-based learning on cloud learning model to enhance undergraduate students critical thinking. [Doctoral dissertation, King Mongkut's University of Technology North Bangkok]. https://doi.org/10.17706/ijeeee.2016.6.3.162-174

Thanapud, M. (2014). The development of problem-based learning instructional package on multiple regressing analysis. [Master's thesis, King Mongkut's University of Technology North Bangkok].

Tumnanchit, B. (2015). The development of problem-based instructional model based on knowledge management approach to enhance the ability to solve problem among undergraduate students. [Doctoral dissertation, King Mongkut's University of Technology North Bangkok].

Ulger, K. (2018). The effect of problem-based learning on the creative thinking and critical thinking disposition of students in visual arts education. Interdisciplinary Journal of Problem-Based learning, 12(1), 3-6. https://doi.org/10.7771/1541-5015.1649

Woods, D. R. (1994). Problem-based learning: How to gain the most from PBL. DR Woods.

Zeichner, K., \& Liston, D. (1987). Teaching student teachers to reflect. Harvard Educational Review, 57(1), 23-49. https://doi.org/10.17763/haer.57.1.j18v7162275t1w3w

\section{Copyrights}

Copyright for this article is retained by the author(s), with first publication rights granted to the journal.

This is an open-access article distributed under the terms and conditions of the Creative Commons Attribution license (http://creativecommons.org/licenses/by/4.0/). 